\title{
Microgram Per Milliliter Per Milligram Per Kilogram Per Day
}

National Cancer Institute

\section{Source}

National Cancer Institute. Microgram Per Milliliter Per Milligram Per Kilogram Per Day. NCI Thesaurus. Code C105474.

A dose calculation unit expressed in microg rams per milliliter, divided by milligram per kilogram per day. 